BMJ Open Sport \& Exercise Medicine

\section{Implementation of the Activate injury prevention exercise programme in English schoolboy rugby union}

To cite: Barden C, Stokes KA, McKay CD. Implementation of the Activate injury prevention exercise programme in English schoolboy rugby union. BMJ Open Sport \& Exercise Medicine 2021;7:e01018. doi:10.1136/ bmjsem-2020-001018

- Additional online supplemental material is published online only. To view, please visit the journal online (http://dx.doi.org/10.1136/ bmjsem-2020-001018)

Accepted 8 April 202
Check for updates

(c) Author(s) (or their employer(s)) 2021. Re-use permitted under CC BY. Published by BMJ.

${ }^{1}$ Department for Health, University of Bath, Bath, UK ${ }^{2}$ Rugby Football Union, Twickenham, UK ${ }^{3}$ Centre for Motivation and Health Behaviour Change, University of Bath, Bath, UK

Correspondence to Craig Barden;

c.barden@bath.ac.uk

\section{ABSTRACT}

Objectives The implementation of the Activate injury prevention exercise programme has not been assessed in an applied context. This study aimed to (1) describe the knowledge and perceptions of school rugby coaches and players towards injury risk, prevention and Activate and (2) evaluate Activate implementation in schoolboy rugby using the reach, effectiveness, adoption, implementation and maintenance framework.

Methods Bespoke electronic surveys were administered to coaches (including support staff) and players at participating English schools (2018-2020). Most questions and statements were answered using a 7-point Likert scale. At baseline, participants detailed their Activate awareness and perceptions of injury risk and prevention in schoolboy rugby. At postseason, participants reported Activate use throughout the study and their perceptions towards the programme.

Results At baseline, significant differences existed between coaches $(n=106)$ and players $(n=571)$ in Activate awareness $\left(75 \%\right.$ and $13 \%$ respectively; $\chi^{2}=173.5$, $\mathrm{p}<0.001)$. Coaches perceived rugby had a significantly greater injury risk than players, while holding more positive perceptions towards injury prevention. At postseason, coaches reported greater Activate adoption compared with players $\left(76 \%\right.$ and $18 \%$ respectively; $\left.\chi^{2}=41.8, p<0.001\right)$; $45 \%$ of players were unaware if they used the programme. Median session adherence was twice weekly, with a median duration of $10-15 \mathrm{~min}$. This suggests Activate was not implemented as intended, with recommendations of three 20 min sessions per week. Both groups identified common barriers to implementation, such as lack of time and inclusion of a ball.

Conclusion Coaches are instrumental in the decision to implement Activate. Targeting behavioural change in these individuals is likely to have the greatest impact on intervention uptake.

\section{INTRODUCTION}

The Rugby Football Union (RFU), England's rugby union governing body, has been championing the Activate injury prevention exercise programme. The 20 min warm-up, designed to be completed prior to training and matches, has shown to be efficacious in reducing youth rugby injury risk. ${ }^{1}$ There are three age group-specific programme
What is already known

Activate is efficacious in reducing injury risk in English schoolboy rugby union

Activate implementation has not been evaluated

What are the new findings

- Coaches reported significantly greater baseline Activate awareness than players $(75 \%$ and $18 \%$, respectively).

- Coaches had significantly greater Activate adoption during the study period (76\% and $13 \%)$.

- Coaches appear to be critical in the adoption and delivery of Activate in a school rugby environment.

- Focus on behavioural change in coaches will likely have the greatest effect of Activate implementation. Addressing coach barriers and using behavioural change theories may aid this.

available, under-15/16/18, incorporating balance, resistance and plyometric exercises with four progressive phases to be completed throughout the season. ${ }^{12}$ In a randomised controlled trial of English schoolboy rugby (under-15 to under-18 years old), a $72 \%$ reduction in overall match injuries and a $59 \%$ reduction in concussions were reported in teams maintaining full compliance through a season ( $\geq 3$ times per week). However, only $16 \%$ of teams in the intervention arm completed Activate as prescribed. If highly resourced schools, supported by a research team, could not maintain compliance over a single season, it raises questions regarding Activate's longer-term effectiveness given the complexity of implementing such interventions in broader sporting contexts. ${ }^{34}$

Injury prevention programmes across various sports have been impacted by poor implementation. ${ }^{5-7}$ The $11+$ (previously FIFA $11+$ ) is perhaps the most widely evaluated programme, with meta-analyses revealing a $20 \%-70 \%$ reduction in injury rates across various settings. ${ }^{8-10}$ However, 
in 2015 , only $10 \%$ of national football associations endorsed the programme. ${ }^{11}$ Low end-user awareness and adoption have been reported worldwide, ${ }^{12-14}$ highlighting the difficulty in successfully disseminating and implementing such interventions. ${ }^{4}$ Numerous contextual complexities influence the transfer of findings from research to practice, including individual perceptions, social influences, political pressures and physical demands. ${ }^{15-17}$ Many of these factors are not evaluated in research or addressed in practice, possibly due to the misconception that people will automatically adopt efficacious interventions because injury prevention is of high priority. ${ }^{18} 19$

Evaluating influences on end-user behaviour is a critical step towards successful implementation. ${ }^{3}$ This is particularly important in community-based environments where users may be volunteers, lack adequate training or are constrained by time and resources. ${ }^{20}$ One tool used to evaluate the implementation of public health interventions is the reach, effectiveness, adoption, implementation and maintenance (RE-AIM) framework. ${ }^{21}$ Briefly, the framework assesses an intervention through five dimensions (table 1); reach (R), effectiveness (E), adoption (A), implementation (I) and maintenance (M), with barriers and facilitators occurring at each dimension. Sport-specific modifications have been recommended to the original framework, ${ }^{22}$ including evaluating each dimension at different hierarchical levels (eg, coaches and players) because differences in knowledge, perceptions and contextual factors at different levels can influence intervention implementation. This was highlighted in a population of South African schoolboy rugby coaches and players, where awareness and knowledge of the BokSmart injury prevention programme significantly differed between these two groups. ${ }^{23}$ RE-AIM suggests that for interventions to have their desired impact, they need to be well known, adopted and implemented over prolonged periods. This is relevant for sports injury prevention programmes, ${ }^{1}{ }^{24}$ yet research heavily focuses on effectiveness with little assessment of the remaining dimensions. ${ }^{25}{ }^{26}$ Only efficacy has been assessed for Activate in school rugby.

End-user perceptions influence injury prevention behaviours, ${ }^{3}$ thus evaluating these in school rugby coaches, support staff and players would provide valuable information to aid Activate implementation. Therefore, this study's objectives were to (1) describe and compare baseline knowledge and perceptions of rugby union coaches (including support staff) and players towards injury risk, injury prevention and Activate and (2) evaluate Activate's 'reach', 'adoption', 'effectiveness', 'implementation' and 'maintenance' in English schoolboy rugby.

\section{METHODS}

\section{Prestudy Activate implementation}

Following publication of an efficacy study in July $2017,{ }^{1}$ the RFU began disseminating Activate through online resources and coach development events, offering free regional training workshops for coaches and support staff registering their interest on the RFU website. In 2018, regional workshops were replaced by a 'workshop on request' system and all online resources became openly available and immediately downloadable on the website with no need to register. School coaches were free to take part in these activities, but schools were not specifically targeted through advertising campaigns or workshop deliveries prior to the 2018 season. Activate dissemination and implementation was completed by the RFU. No information is available regarding the number of website registrations or workshops run by the RFU external to this study.

\section{Recruitment}

The research team compiled a comprehensive, but not exhaustive, database of English schools $(n=289)$.

Table 1 RE-AIM dimension definitions

\begin{tabular}{|c|c|c|}
\hline Dimension & RE-AIM definition ${ }^{21}$ & Operationalised definition \\
\hline Reach & $\begin{array}{l}\text { Proportion of target population that } \\
\text { participated in the intervention }\end{array}$ & $\begin{array}{l}\text { Percentage of coaches and players (end-users) } \\
\text { aware of Activate }\end{array}$ \\
\hline Effectiveness & - Success rate if implemented as intended & $\begin{array}{l}\text { Perception that Activate reduced injury risk } \\
\text { among end-users }\end{array}$ \\
\hline Adoption & $\begin{array}{l}\text { Proportion of settings and practices adopting } \\
\text { the intervention }\end{array}$ & $\begin{array}{l}\text { Percentage of coaches self-reporting using } \\
\text { Activate (adoption and delivery to players) } \\
\text { Percentage of players self-reporting using } \\
\text { Activate }\end{array}$ \\
\hline Implementation & $\begin{array}{l}\text { Extent to which the intervention is implemented } \\
\text { as intended }\end{array}$ & $\begin{array}{l}\text { Percentage of end-users using Activate as } \\
\text { intended (adherence and fidelity) }\end{array}$ \\
\hline Maintenance & $\begin{array}{l}\text { Extent to which the programme is maintained } \\
\text { over time }\end{array}$ & $\begin{array}{l}\text { Perception that Activate could be maintained } \\
\text { over multiple seasons } \\
\text { Percentage of end-users intending to use } \\
\text { Activate next season }\end{array}$ \\
\hline
\end{tabular}

RE-AIM, reach, effectiveness, adoption, implementation and maintenance. 
School names were retrieved from the RFU website for those participating in under-12 to under-19 competitions. Email addresses were obtained for school rugby staff members whom possibly influenced team warm-up procedures (directors/heads of rugby, assistant coaches, medical staff, conditioning staff). Additionally, the RFU publicised the study through coach correspondence and social media to aid recruitment, directing potential participants to contact the research team. School rugby seasons started between July and September and finished between December (generally independent schools) and April (government-funded state schools). Recruitment emails were sent inviting schools to join the project in preseason of two consecutive seasons (July-September 2018 and 2019). If a response to the initial recruitment email was not received, a follow-up email was sent 2 weeks later, after which it was accepted that the school did not wish to participate.

At participating schools, a gatekeeper (primarily the coach) was sent electronic links (https://www.onlinesurveys.ac.uk/) to information sheets and consent forms to forward onto team staff (hereby referred to as coaches), players and their parents/guardians. Patients and public were not involved in the study design.

\section{Baseline measures}

Participants were asked to complete an online baseline survey detailing: (A) demographics, (B) perceptions of injury risk in rugby, $(\mathrm{C})$ perceptions of injury prevention in rugby and (D) Activate awareness (online supplemental file 1). The coach survey included 26 questions. A refined player survey (13 questions) was used to maximise response rates, containing questions that were reworded to enable comprehension by the youngest participants (Flesch reading ease score $=6.7$ ).

Questions in sections B, C and D were taken from studies investigating end-user perceptions and intentions towards the $11+.{ }^{12} 1827$ These studies evaluated face and content validity of the survey. Questions were reworded to ask about rugby and Activate, rather than soccer and the 11+. These amendments were face validated by the research team prior to administration. Activate-specific questions were aligned with the relevant RE-AIM dimensions, using the operationalised definitions presented in table 1 to facilitate interpretation. The survey consisted of single answer multiple choice questions, multiple answer multiple choice questions and scale/rank questions. Scale/rank questions were answered on a 7-point Likert scale, for example 'strongly agree' to 'strongly disagree'. To prevent bias towards the left of the scale ${ }^{28}$ Likert scales were reversed randomly throughout.

Activate was not mentioned in recruitment correspondence to prevent bias in the 'awareness' questions. Gatekeepers were sent a link to the Activate website after completing the baseline survey as a coaching resource, but schools were not instructed to adopt the programme.

\section{Postseason measures}

Postseason surveys were administered electronically to coaches and players who completed the baseline survey (online supplemental file 1). These duplicated the baseline survey but contained an additional section (E) investigating Activate use (adoption, implementation and maintenance) and perceptions of effectiveness. Facilitators and barriers were investigated with participants selecting multiple-answer prefilled responses if they agreed with the statement provided. This section used questions from previous studies investigating the $11+{ }^{12} 1827$ and an unpublished pilot study of Activate implementation in men's community rugby. ${ }^{29}$

\section{Analysis}

Descriptive statistics were used to summarise continuous (mean, SD) and discrete (percentages (\%)) participant demographic data. Ordinal data collected from individual Likert scale responses were presented using medians, IQR, percentages (\%) and 95\% CI. Only participants who reported using Activate were included in the analysis of feedback relating to the programme.

Non-parametric Wilcoxon-Mann-Whitney tests used to assess differences between coach and player Likert scale responses. A $2 \times 2 \chi^{2}$ was used to assess differences between groups for dichotomous responses (yes/no; 'unsure' responses were excluded from analysis). Statistical significance was accepted at a Bonferroni adjusted $\alpha$ level $\mathrm{p} \leq 0.002(0.05 / 22$ statistical tests) to reduce the risk of type I error.

\section{Patient and public involvement}

Patients and/or the public were not involved in the design, or conduct, or reporting, or dissemination plans of this research.

\section{RESULTS \\ Demographics}

Recruitment emails were sent to 289 schools (148 private, 141 state). At baseline, 106 coaches from 31 schools (11\%; 25 private, 6 state) and 571 players from 23 schools (8\%; 17 private, 6 state) responded to the survey (table 2 ).

\section{Perceptions}

Coaches 'slightly agree $d$ ' that rugby players are at high risk of injury, believing injuries have negative effects on team performance and long-term player health (table 3 ). Coaches (51\% 'agreed', 95\% CI 41 to 61 ) held significantly stronger perceptions than players that rugby injuries could be prevented (45\% 'agreed', 95\% CI 41 to $49 ; \mathrm{z}=-3.3, \mathrm{p} \leq 0.001)$. Most coaches 'strongly agreed' that injury prevention exercises should be performed by rugby players, 'agreeing' that a rugby specific warm-up could reduce injury risk while improving players' physical characteristics. 
Open access

Table 2 Participants' baseline characteristics

\begin{tabular}{|c|c|c|c|}
\hline Question/demographic & Response & $\begin{array}{l}\text { Coaches } \\
\text { n (\%) }\end{array}$ & $\begin{array}{l}\text { Players } \\
\text { n (\%) }\end{array}$ \\
\hline \multirow[t]{2}{*}{ School type } & Private (independent) & $87(82 \%)$ & $393(69 \%)$ \\
\hline & State (government funded) & $19(18 \%)$ & $178(31 \%)$ \\
\hline Participant age & Mean Age & $37.4( \pm 10.5)$ & $15.3( \pm 2.0)$ \\
\hline \multirow[t]{8}{*}{ What is your role? } & Team staff & $106(100 \%)$ & - \\
\hline & Director of Sport & $9(8 \%)$ & - \\
\hline & Head coach/Director of rugby & $41(39 \%)$ & - \\
\hline & Assistant coach & $36(34 \%)$ & - \\
\hline & Team manager & $13(12 \%)$ & - \\
\hline & Conditioning coach & $2(2 \%)$ & - \\
\hline & Medical practitioner & $5(5 \%)$ & - \\
\hline & Player & - & $571(100 \%)$ \\
\hline \multicolumn{4}{|c|}{ If coaching, how many years coaching experience do you have? } \\
\hline & Less than 2 years & $13(13 \%)$ & - \\
\hline & $2-3$ years & $10(10 \%)$ & - \\
\hline & $4-5$ years & $11(11 \%)$ & - \\
\hline & $6+$ years & $65(66 \%)$ & - \\
\hline \multicolumn{4}{|c|}{ What is the highest level you have coached? } \\
\hline & School/club & $54(55 \%)$ & - \\
\hline & Regional junior academy & $14(14 \%)$ & - \\
\hline & County/constituent body & $12(12 \%)$ & - \\
\hline & Divisional & $8(8 \%)$ & - \\
\hline & Professional & $3(3 \%)$ & - \\
\hline & International & $7(7 \%)$ & - \\
\hline \multicolumn{4}{|c|}{ What is the highest coaching qualification you hold? } \\
\hline & RFU level 1 & $16(18 \%)$ & - \\
\hline & RFU level 2 & $38(42 \%)$ & - \\
\hline & RFU level 3 & $19(21 \%)$ & - \\
\hline & RFU level 4 & $5(5 \%)$ & - \\
\hline & Other & $13(14 \%)$ & - \\
\hline \multicolumn{4}{|c|}{ When did you obtain this qualification? } \\
\hline & Less than 2 years ago & $20(26 \%)$ & - \\
\hline & $2-3$ years ago & $12(16 \%)$ & - \\
\hline & $4-5$ years ago & $18(23 \%)$ & - \\
\hline & More than 5 years ago & $27(35 \%)$ & - \\
\hline \multicolumn{4}{|c|}{ What age group do you coach/play in? } \\
\hline & Under-12/13 & $16(13 \%)$ & $107(19 \%)$ \\
\hline & Under-14/15 & $34(27 \%)$ & 167 (29\%) \\
\hline & Under-16 & $9(7 \%)$ & $26(5 \%)$ \\
\hline & Under-18/19 & $42(33 \%)$ & $271(47 \%)$ \\
\hline & Multiple age groups & $5(4 \%)$ & - \\
\hline \multicolumn{4}{|c|}{ Have you previously played competitive rugby? } \\
\hline & No & $9(8 \%)$ & - \\
\hline & Yes & $97(92 \%)$ & - \\
\hline
\end{tabular}


Table 2 Continued

\begin{tabular}{llcl}
\hline Question/demographic & Response & $\begin{array}{l}\text { Coaches } \\
\text { n (\%) }\end{array}$ & $\begin{array}{l}\text { Players } \\
\text { n (\%) }\end{array}$ \\
\hline & School & $12(12 \%)$ & - \\
& Age group community club & $4(4 \%)$ & - \\
& Junior academy Rugby & $3(3 \%)$ & - \\
& University & $11(11 \%)$ & - \\
& Adult community club & $47(48 \%)$ & - \\
& Professional & $13(13 \%)$ & -
\end{tabular}

Do you have a current medical or first aid qualification?

\begin{tabular}{|c|c|c|}
\hline No & $30(28 \%)$ & - \\
\hline Yes & $76(72 \%)$ & - \\
\hline \multicolumn{3}{|c|}{ Have you ever used a specific programme to reduce your/players injury risk? } \\
\hline No & $65(61 \%)$ & $401(70 \%)$ \\
\hline Yes & $41(39 \%)$ & $170(30 \%)$ \\
\hline \multicolumn{3}{|c|}{ In the past 12 months, have you experienced a rugby injury that caused you to miss a game or training session? } \\
\hline No & - & $244(43 \%)$ \\
\hline Yes & - & $327(57 \%)$ \\
\hline \multicolumn{3}{|c|}{ If yes, did it cause you to miss school or work for at least 1 day? } \\
\hline No & - & $218(67 \%)$ \\
\hline Yes & - & 109 (33\%) \\
\hline
\end{tabular}

RFU, Rugby Football Union.

Significant differences existed between coaches and players when asked 'who is responsible for injury prevention?' (figure 1). Both groups rated themselves highest (97\%, $95 \%$ CI $94 \%$ to $100 \%$ and $87 \%, 95 \%$ CI $84 \%$ to $90 \%$, respectively). Coaches felt injury prevention was a collective responsibility across all roles, except team managers $(4 \%)$, while players thought responsibility was confined to themselves, head coaches and conditioning staff (all remaining roles $<30 \%$ ).

\section{Reach and adoption (baseline)}

At baseline, most coaches were aware of Activate (75\%, $95 \%$ CI $67 \%$ to $83 \%$; figure 2) but fewer than half reported previous (48\%, 95\% CI 38\% to 58\%) or current use $(37 \%, 95 \%$ CI $28 \%$ to $46 \%)$. Coach awareness largely came from peers $(45 \%, 95 \%$ CI $36 \%$ to $54 \%)$, the RFU website $(43 \%, 95 \% \mathrm{CI} 33 \%$ to $52 \%)$ and RFU community rugby coaches $(24 \%, 95 \%$ CI $16 \%$ to $32 \%)$ who were employed by the RFU to support community schools and clubs.

Significantly fewer players were aware of Activate at baseline than coaches (13\%, 95\% CI $10 \%$ to $16 \%$; $\left.\chi^{2}=173.5, \mathrm{p}<0.001\right)$. A small percentage reported previously or currently using Activate (both $11 \%, 95 \%$ CI $8 \%$ to $14 \%$ ), with a large proportion unsure if they currently used the programme (46\%, 95\% CI $42 \%$ to $50 \%)$. Player awareness mainly came from their coaches $(77 \%, 95 \% \mathrm{CI}$ $67 \%$ to $87 \%$ ), with all remaining options under $14 \%$.

\section{Effectiveness (postseason)}

Coaches with experience using Activate believed it could reduce injury risk (53\% 'agreed', 95\% CI $41 \%$ to $65 \%$; table 4). Adopting coaches held stronger perceptions it prevented injuries in their team (43\% 'slightly agreed, 95\% CI $30 \%$ to $56 \%$ ) than players ( $41 \%$ 'neutral', 95\% CI $28 \%$ to $54 \% ; \mathrm{z}=-3.3, \mathrm{p}<0.001$ ).

\section{Adoption}

Coaches reported significantly greater adoption rates than players during the study period $(76 \%, 95 \%$ CI $66 \%$ to $86 \%$; and $18 \%, 95 \%$ CI $14 \%$ to $22 \%$, respectively; $\left.\chi^{2}=41.8, \mathrm{p}<0.001\right)$. Players were largely unaware whether they used Activate during the season (45\%, 95\% CI 39 to $50)$. All adopting coaches reported using the programme prior to training, though $16 \%$ (95\% CI $6 \%$ to $25 \%$ ) did not use it prior to matches.

\section{Implementation}

Adopting coaches had a median adherence of two sessions per week $(45 \%, 95 \%$ CI $32 \%$ to $58 \%)$, with $33 \%$ (95\% CI $21 \%$ to $45 \%$ ) using Activate thrice weekly as recommended. Median duration prior to training was $10-15 \mathrm{~min}$ (50\%, $95 \%$ CI $37 \%$ to $63 \%$ ), with $28 \%$ of coaches taking 15-20 min to complete Activate (95\% CI 16\% to 40\%). Adopting coaches reported median duration prior to matches was $10-15 \mathrm{~min}(31 \%, 95 \%$ CI $19 \%$ to $43 \%)$, with a third spending $5-10 \mathrm{~min}(33 \%, 95 \%$ CI $21 \%$ to $45 \%)$. 
Table 3 Baseline perceptions of coaches and players towards injury risk and injury prevention, percentage responding per answer $(95 \% \mathrm{Cl})$

\begin{tabular}{|c|c|c|c|c|c|c|c|c|c|c|}
\hline \multirow{2}{*}{ Statement... } & \multirow[b]{2}{*}{ Role } & \multirow[b]{2}{*}{$\mathbf{n}$} & \multirow{2}{*}{$\begin{array}{l}\text { Median } \\
\text { (IQR) }\end{array}$} & \multicolumn{3}{|c|}{ Strongly agree } & \multicolumn{2}{|l|}{ Neither } & \multicolumn{2}{|c|}{ Strongly disagree } \\
\hline & & & & 1 & 2 & 3 & 4 & 5 & 6 & 7 \\
\hline \multicolumn{11}{|l|}{ Rugby Injuries can... } \\
\hline \multirow{2}{*}{...shorten a player's career } & Coach & 106 & 1 & $74 \%$ & $16 \%$ & $6 \%$ & $4 \%$ & $0 \%$ & $0 \%$ & $0 \%$ \\
\hline & & & $(1-2)$ & $(66-82)$ & $(9-23)$ & $(1-11)$ & $(0-8)$ & $(-)$ & $(-)$ & $(-)$ \\
\hline \multirow{2}{*}{$\begin{array}{l}\ldots \text { cause physical problems } \\
\text { later in life }\end{array}$} & Coach & 106 & 1 & $61 \%$ & $28 \%$ & $10 \%$ & $1 \%$ & $0 \%$ & $0 \%$ & $0 \%$ \\
\hline & & & $(1-2)$ & $(52-70)$ & $(19-37)$ & $(4-16)$ & $(0-3)$ & $(-)$ & $(-)$ & $(-)$ \\
\hline \multirow{2}{*}{$\begin{array}{l}\text {... have a negative impact on } \\
\text { team performance }\end{array}$} & Coach & 106 & 2 & $21 \%$ & $37 \%$ & $14 \%$ & $12 \%$ & $5 \%$ & $7 \%$ & $6 \%$ \\
\hline & & & $(2-4)$ & $(13-29)$ & $(28-46)$ & $(7-21)$ & $(6-18)$ & $(1-9)$ & $(2-12)$ & $(1-11)$ \\
\hline \multirow{2}{*}{$\begin{array}{l}\text {... have a negative impact on } \\
\text { a player's quality of life }\end{array}$} & Coach & 106 & 2 & $21 \%$ & $40 \%$ & $23 \%$ & $4 \%$ & $7 \%$ & $3 \%$ & $2 \%$ \\
\hline & & & $(2-3)$ & $(13-29)$ & $(31-49)$ & $(15-31)$ & $(0-8)$ & $(2-12)$ & $(0-6)$ & $(0-5)$ \\
\hline \multirow{4}{*}{$\begin{array}{l}\text { Rugby players are at high risk } \\
\text { of suffering an injury }\end{array}$} & Coach & 106 & 3 & $15 \%$ & $33 \%$ & $29 \%$ & $8 \%$ & $9 \%$ & $3 \%$ & $2 \%$ \\
\hline & & & (2-3) & (8-22) & $(25-43)$ & (19-37) & $(3-13)$ & $(4-14)$ & $(0-6)$ & $(0-5)$ \\
\hline & Player & 571 & 3 & $9 \%$ & $34 \%$ & $28 \%$ & $10 \%$ & $9 \%$ & $7 \%$ & $3 \%$ \\
\hline & & & (2-4) & $(7-11)$ & (30-38) & (24-32) & $(8-12)$ & $(7-11)$ & (5-9) & (2-4) \\
\hline \multirow{4}{*}{$\begin{array}{l}\text { I expect/a player I coach to } \\
\text { sustain an injury sometime } \\
\text { during the next season }\end{array}$} & Coach & 105 & 3 & $15 \%$ & $34 \%$ & $28 \%$ & $8 \%$ & $5 \%$ & $9 \%$ & $1 \%$ \\
\hline & & & $(2-3)$ & (8-22) & (25-43) & $(19-37)$ & $(3-13)$ & $(1-9)$ & $(4-14)$ & $(0-3)$ \\
\hline & Player & 571 & 3 & $5 \%$ & $17 \%$ & $31 \%$ & $18 \%$ & $9 \%$ & $15 \%$ & $5 \%$ \\
\hline & & & $(3-5)$ & $(3-7)$ & (14-20) & (27-35) & $(15-21)$ & $(7-11)$ & $(12-18)$ & (3-7) \\
\hline \multirow{4}{*}{$\begin{array}{l}\text { It is possible to prevent some } \\
\text { rugby injuries }\end{array}$} & Coach & 105 & 2 & $36 \%$ & $51 \%$ & $11 \%$ & $0 \%$ & $1 \%$ & $1 \%$ & $0 \%$ \\
\hline & & & $(1-2)$ & $(27-45)$ & $(41-61)$ & $(5-17)$ & $(-)$ & $(0-3)$ & $(0-3)$ & $(-)$ \\
\hline & Player* & 571 & 2 & $26 \%$ & $45 \%$ & $22 \%$ & $2 \%$ & $2 \%$ & $3 \%$ & $0 \%$ \\
\hline & & & $(1-3)$ & $(22-30)$ & (41-49) & (19-25) & $(1-3)$ & $(1-3)$ & (2-4) & $(-)$ \\
\hline \multicolumn{11}{|c|}{ Exercises which have been shown to prevent injuries should be.. } \\
\hline \multirow[t]{4}{*}{...performed by rugby players } & Coach & 106 & 1 & $52 \%$ & $45 \%$ & $3 \%$ & $0 \%$ & $0 \%$ & $0 \%$ & $0 \%$ \\
\hline & & & $(1-2)$ & (42-62) & $(36-54)$ & $(0-6)$ & $(-)$ & $(-)$ & $(-)$ & $(-)$ \\
\hline & Player & 571 & 2 & $50 \%$ & $42 \%$ & $5 \%$ & $2 \%$ & $1 \%$ & $0 \%$ & $0 \%$ \\
\hline & & & $(1-2)$ & $(46-54)$ & $(38-46)$ & $(3-7)$ & $(1-3)$ & $(0-2)$ & $(-)$ & $(-)$ \\
\hline \multirow{2}{*}{$\begin{array}{l}\text {...incorporated into schools' } \\
\text { rugby training }\end{array}$} & Coach & 106 & 2 & $44 \%$ & $43 \%$ & $4 \%$ & $0 \%$ & $1 \%$ & $0 \%$ & $8 \%$ \\
\hline & & & $(1-2)$ & $(35-53)$ & $(34-52)$ & $(0-8)$ & $(-)$ & $(0-3)$ & $(-)$ & $(3-13)$ \\
\hline \multirow{2}{*}{$\begin{array}{l}\ldots \text { varied and progressed over } \\
\text { time }\end{array}$} & Coach & 106 & 2 & $43 \%$ & $47 \%$ & $6 \%$ & $4 \%$ & $0 \%$ & $0 \%$ & $0 \%$ \\
\hline & & & $(1-2)$ & $(34-52)$ & $(37-57)$ & $(1-11)$ & $(0-8)$ & $(-)$ & $(-)$ & $(-)$ \\
\hline \multicolumn{11}{|l|}{ Completing a rugby specific warm- } \\
\hline \multirow{4}{*}{$\begin{array}{l}\text {...reduce the risk of players } \\
\text { sustaining an injury }\end{array}$} & Coach & 106 & 2 & $35 \%$ & $48 \%$ & $15 \%$ & $2 \%$ & $1 \%$ & $0 \%$ & $0 \%$ \\
\hline & & & $(1-2)$ & $(26-44)$ & $(38-58)$ & $(8-22)$ & $(0-5)$ & $(0-3)$ & $(-)$ & $(-)$ \\
\hline & Player & 571 & 2 & $44 \%$ & $42 \%$ & $10 \%$ & $2 \%$ & $2 \%$ & $0 \%$ & $0 \%$ \\
\hline & & & $(1-2)$ & $(40-48)$ & $(38-46)$ & $(8-12)$ & $(1-3)$ & $(1-3)$ & $(-)$ & $(-)$ \\
\hline $\begin{array}{l}\text {... improve physical } \\
\text { characteristics such as } \\
\text { balance, agility and strength }\end{array}$ & Coach & 106 & $\begin{array}{l}2 \\
(1-2)\end{array}$ & $\begin{array}{l}29 \% \\
(20-38)\end{array}$ & $\begin{array}{l}48 \% \\
(38-58)\end{array}$ & $\begin{array}{l}12 \% \\
(6-18)\end{array}$ & $\begin{array}{l}4 \% \\
(0-8)\end{array}$ & $\begin{array}{l}2 \% \\
(0-5)\end{array}$ & $\begin{array}{l}1 \% \\
(0-3)\end{array}$ & $\begin{array}{l}4 \% \\
(0-8)\end{array}$ \\
\hline
\end{tabular}

$\mathrm{n}=$ number of respondents per statement.

${ }^{*} \mathrm{P} \leq 0.001$ when assessing coach versus player responses.

Of adopting players, $41 \%$ (95\% CI $28 \%$ to $54 \%$ ) reported completing two sessions per week $(41 \%, 95 \%$ CI $28 \%$ to $54 \%$ ), with $33 \%$ (95\% CI $21 \%$ to $46 \%$ ) using Activate three times per week. There was no difference between coach and player adherence $\left(\chi^{2}=-0.1, \mathrm{p}=0.9\right)$.

\section{Maintenance}

Most coaches 'agreed' Activate contained adequate variations/progressions (55\%, 95\% CI $43 \%$ to $67 \%$ ) and could be maintained over multiple seasons $(58 \%, 95 \%$ CI $46 \%$ to $70 \%$ ); however, $44 \%$ (95\% CI $46 \%$ to $70 \%$ ) felt 


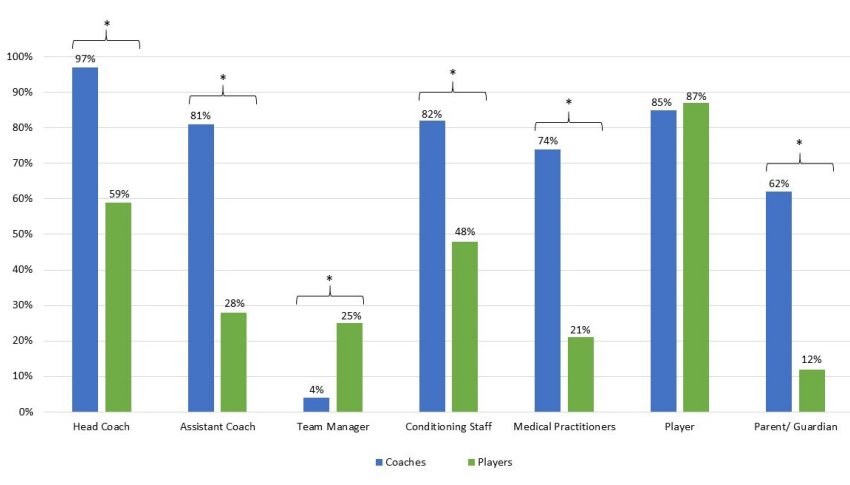

Figure 1 Baseline coach and player response to 'who is responsible for injury prevention'? * $\mathrm{P}<0.001$ when assessing coach versus player responses.

it needed to be improved and $47 \%$ (95\% CI $35 \%$ to $59 \%$ ) suggested their school develop their own version. Coaches had significantly greater intention $(43 \%$ 'strongly agreed', $43 \%, 95 \%$ CI $32 \%$ to $55 \%$ ) to use Activate next season than players (54\% 'neutral', 95\% CI $48 \%$ to $\left.60 \% ; \chi^{2}=-5.5, \mathrm{p}<0.001\right)$.

\section{Facilitators and barriers}

Coaches with experience using Activate (in this study or previously) perceived its positives to be 'learning exercises to reduce my players' injury risk' (73\%, 95\% CI 62\% to $84 \%$ ), followed by 'completing exercises different to usual rugby training' $(65 \%, 95 \%$ CI $53 \%$ to $77 \%)$. The most commonly reported barrier from coaches was the lack of ball work within the programme $(45 \%, 95 \% \mathrm{CI}$ $33 \%$ to $57 \%)$. Nearly a third of coaches $(31 \%, 95 \%$ CI $19 \%$ to $43 \%$ ) reported that players disliking Activate was a barrier. Some coaches felt Activate limited their time to train $(29 \%, 95 \%$ CI $18 \%$ to $40 \%), 32 \%$ recommending reducing the programmes duration $(95 \%$ CI $20 \%$ to $44 \%)$.

There was no consensus from players regarding facilitators to using Activate. Commonly reported player barriers were the lack of ball work $(37 \%, 95 \%$ CI $24 \%$ to $50 \%)$ and the resulting lack of time to train (28\%, 95\% CI $16 \%$ to $40 \%)$. Only $6 \%(95 \%$ CI $0 \%$ to $12 \%)$ of players with

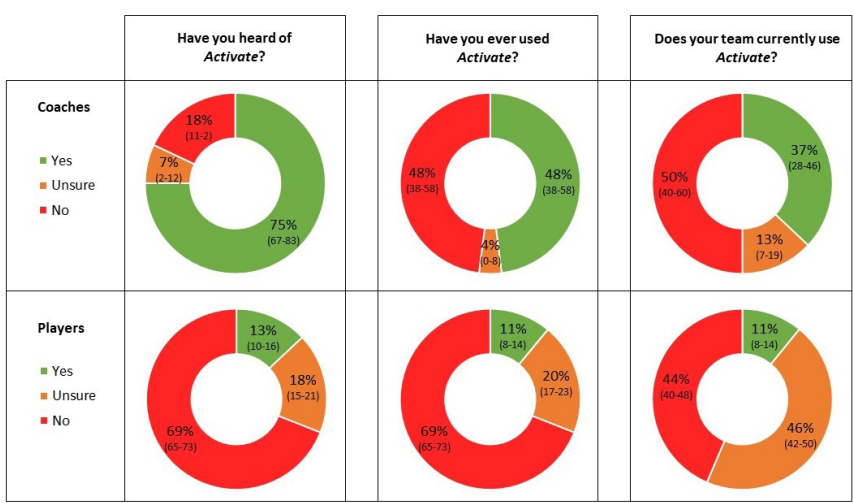

Figure 2 Baseline coach and player responses to Activate awareness and adoption. percentage responding per answer $(95 \% \mathrm{Cl})$.
Activate experience said they did not like completing the programme, although $22 \%$ (95\% CI $11 \%$ to $33 \%$ ) of players reported the exercises were boring.

\section{DISCUSSION}

This study sought to describe the knowledge and perceptions of schoolboy rugby coaches and players towards injury risk, prevention and the Activate programme. Coaches had significantly greater perceptions of rugby injury risk and more positive perceptions towards prevention than players. Coaches had high rates of Activate awareness and adoption. Only a small percentage of players were aware of the programme, with their awareness largely coming from their coaches. Coaches are critical stakeholders in the decision to adopt and deliver Activate in a school context, suggesting implementation strategies should focus on these individuals.

Coaches perceived rugby players were at high risk of injury, agreeing with evidence that injuries can have detrimental effects on team performance, ${ }^{30}$ an athlete's career ${ }^{31}$ and their quality of life. ${ }^{31} 32$ Coaches and players felt it was possible to prevent rugby injuries, identifying the positive effects rugby specific warm-ups can have on injury risk. ${ }^{1334}$ These findings are encouraging as end-user knowledge and perceptions influence outcome behaviour. ${ }^{3}$ However, influences on behaviour are multifactorial ${ }^{181936}$ and the notion that high levels of perceived risk or effectiveness will lead to coaches' adoption ${ }^{6}$ or adherence ${ }^{19}$ is too simplistic. Altering these perceptions should not be the primary strategy for maximising implementation. Using behavioural change theories may provide success in influencing coach behaviour to maximise outcomes for the latter dimensions of RE-AIM. ${ }^{18} 37$

Using the RE-AIM framework, there was good programme reach among coaches. This is especially positive as this study was conducted within 2 years of Activate's launch and more established programmes have reported poorer coach awareness. ${ }^{13} 142738$ Players had poor programme awareness, likely not affecting their exposure in a school environment but hindering autonomous adoption and long-term maintenance. Coaches reported significantly greater adoption rates than players, many of whom were unaware they were completing Activate. This supports the notion that coaches have primary decision-making responsibility and control of injury prevention in youth sport ${ }^{39}$ and directing effort towards behavioural change in these individuals should be a priority. This approach is further advocated given coaches impart their awareness of injury prevention programmes onto their players, ${ }^{23}$ while positively influencing players' injury prevention behaviours. ${ }^{40}$

Hislop et $a l^{1}$ found greatest efficacy when completing Activate three times per week. ${ }^{1}$ Coaches in this present study reported a median adherence of twice weekly. Similar programmes have found significant benefits when 
Table 4 Postseason perceptions from end-users who reported previous Activate use. percentage responding per answer $(95 \% \mathrm{Cl})$

\begin{tabular}{|c|c|c|c|c|c|c|c|c|c|c|c|}
\hline \multirow[b]{2}{*}{ Statement: } & \multirow[b]{2}{*}{ RE-AIM } & \multirow[b]{2}{*}{ Role } & \multirow[b]{2}{*}{$\mathbf{N}$} & \multirow{2}{*}{$\begin{array}{l}\text { Median } \\
\text { (IQR) }\end{array}$} & \multicolumn{2}{|l|}{$\begin{array}{l}\text { Strongly } \\
\text { agree }\end{array}$} & \multicolumn{3}{|l|}{ Neither } & \multicolumn{2}{|l|}{$\begin{array}{l}\text { Strongly } \\
\text { disagree }\end{array}$} \\
\hline & & & & & 1 & 2 & 3 & 4 & 5 & 6 & 7 \\
\hline $\begin{array}{l}\text { Activate can prevent rugby injuries } \\
\text { in your team }\end{array}$ & $\mathrm{E}, \mathrm{A}$ & Coach & 62 & $\begin{array}{l}2 \\
(1-2)\end{array}$ & $\begin{array}{l}26 \% \\
(15-37)\end{array}$ & $\begin{array}{l}53 \% \\
(41-65)\end{array}$ & $\begin{array}{l}15 \% \\
(6-24)\end{array}$ & $\begin{array}{l}3 \% \\
(0-7)\end{array}$ & $\begin{array}{l}0 \% \\
(-)\end{array}$ & $\begin{array}{l}0 \% \\
(-)\end{array}$ & $\begin{array}{l}3 \% \\
(0-7)\end{array}$ \\
\hline \multirow[t]{2}{*}{ Activate is rugby specific } & $A, I, M$ & Coach & 62 & $\begin{array}{l}3 \\
(2-5)\end{array}$ & $\begin{array}{l}15 \% \\
(6-24)\end{array}$ & $\begin{array}{l}16 \% \\
(7-25)\end{array}$ & $\begin{array}{l}24 \% \\
(13-35)\end{array}$ & $\begin{array}{l}18 \% \\
(8-28)\end{array}$ & $\begin{array}{l}13 \% \\
(5-21)\end{array}$ & $\begin{array}{l}13 \% \\
(5-21)\end{array}$ & $\begin{array}{l}2 \% \\
(0-5)\end{array}$ \\
\hline & & Player & 57 & $\begin{array}{l}4 \\
(2-4)\end{array}$ & $\begin{array}{l}11 \% \\
(3-19)\end{array}$ & $\begin{array}{l}23 \% \\
(12-34)\end{array}$ & $\begin{array}{l}16 \% \\
(6-26)\end{array}$ & $\begin{array}{l}28 \% \\
(16-40)\end{array}$ & $\begin{array}{l}5 \% \\
(0-11)\end{array}$ & $\begin{array}{l}12 \% \\
(4-20)\end{array}$ & $\begin{array}{l}5 \% \\
(0-11)\end{array}$ \\
\hline \multirow[t]{2}{*}{ Activate is too long } & $A, I, M$ & Coach & 62 & $\begin{array}{l}4 \\
(3-6)\end{array}$ & $\begin{array}{l}2 \% \\
(0-5)\end{array}$ & $\begin{array}{l}16 \% \\
(7-25)\end{array}$ & $\begin{array}{l}21 \% \\
(11-31)\end{array}$ & $\begin{array}{l}22 \% \\
(12-32)\end{array}$ & $\begin{array}{l}11 \% \\
(3-19)\end{array}$ & $\begin{array}{l}23 \% \\
(13-33)\end{array}$ & $\begin{array}{l}5 \% \\
(0-10)\end{array}$ \\
\hline & & Player & 57 & $\begin{array}{l}4 \\
(3-5)\end{array}$ & $\begin{array}{l}2 \% \\
(0-6)\end{array}$ & $\begin{array}{l}16 \% \\
(6-26)\end{array}$ & $\begin{array}{l}12 \% \\
(4-20)\end{array}$ & $\begin{array}{l}42 \% \\
(29-55)\end{array}$ & $\begin{array}{l}12 \% \\
(4-20)\end{array}$ & $\begin{array}{l}11 \% \\
(3-19)\end{array}$ & $\begin{array}{l}5 \% \\
(0-11)\end{array}$ \\
\hline Activate was fun to do & $A, I, M$ & Player & 57 & $\begin{array}{l}4 \\
(3-4)\end{array}$ & $\begin{array}{l}5 \% \\
(0-11)\end{array}$ & $\begin{array}{l}11 \% \\
(3-19)\end{array}$ & $\begin{array}{l}21 \% \\
(10-32)\end{array}$ & $\begin{array}{l}42 \% \\
(29-55)\end{array}$ & $\begin{array}{l}11 \% \\
(3-19)\end{array}$ & $\begin{array}{l}3 \% \\
(0-7)\end{array}$ & $\begin{array}{l}7 \% \\
(0-14)\end{array}$ \\
\hline $\begin{array}{l}\text { Activate contains adequate } \\
\text { variation and progression for our } \\
\text { team }\end{array}$ & $A, I, M$ & Coach & 62 & $\begin{array}{l}2 \\
(2-3)\end{array}$ & $\begin{array}{l}3 \% \\
(0-7)\end{array}$ & $\begin{array}{l}55 \% \\
(43-67)\end{array}$ & $\begin{array}{l}27 \% \\
(16-38)\end{array}$ & $\begin{array}{l}7 \% \\
(1-13)\end{array}$ & $\begin{array}{l}8 \% \\
(1-15)\end{array}$ & $\begin{array}{l}0 \% \\
(-)\end{array}$ & $\begin{array}{l}0 \% \\
(-)\end{array}$ \\
\hline $\begin{array}{l}\text { Activate could be maintained over } \\
\text { multiple seasons by our team }\end{array}$ & $A, I, M$ & Coach & 62 & $\begin{array}{l}2 \\
(2-3)\end{array}$ & $\begin{array}{l}16 \% \\
(7-25)\end{array}$ & $\begin{array}{l}58 \% \\
(46-70)\end{array}$ & $\begin{array}{l}23 \% \\
(13-33)\end{array}$ & $\begin{array}{l}3 \% \\
(0-7)\end{array}$ & $\begin{array}{l}0 \% \\
(-)\end{array}$ & $\begin{array}{l}0 \% \\
(-)\end{array}$ & $\begin{array}{l}0 \% \\
(-)\end{array}$ \\
\hline $\begin{array}{l}\text { Activate reduced my/players injury } \\
\text { risk this season }\end{array}$ & $\mathrm{E}, \mathrm{A}, \mathrm{I}, \mathrm{M}$ & Coach & 58 & $\begin{array}{l}3 \\
(2-4)\end{array}$ & $\begin{array}{l}0 \% \\
(-)\end{array}$ & $\begin{array}{l}26 \% \\
(15-37)\end{array}$ & $\begin{array}{l}43 \% \\
(30-56)\end{array}$ & $\begin{array}{l}9 \% \\
(2-16)\end{array}$ & $\begin{array}{l}14 \% \\
(5-23)\end{array}$ & $\begin{array}{l}7 \% \\
(0-14)\end{array}$ & $\begin{array}{l}2 \% \\
(0-6)\end{array}$ \\
\hline & & Player $^{*}$ & 54 & $\begin{array}{l}4 \\
(3-5)\end{array}$ & $\begin{array}{l}6 \% \\
(0-12)\end{array}$ & $\begin{array}{l}4 \% \\
(0-9)\end{array}$ & $\begin{array}{l}17 \% \\
(7-27)\end{array}$ & $\begin{array}{l}41 \% \\
(28-54)\end{array}$ & $\begin{array}{l}22 \% \\
(11-33)\end{array}$ & $\begin{array}{l}7 \% \\
(0-14)\end{array}$ & $\begin{array}{l}4 \% \\
(0-9)\end{array}$ \\
\hline
\end{tabular}

Percentage responding per answer (95\% C).

${ }^{*} \mathrm{P}<0.001$ when assessing coach versus player responses.

RE-AIM, reach, effectiveness, adoption, implementation and maintenance.

used two times per week ${ }^{41}$ so this level of adherence may be sufficient to provide a preventative effect. However, Activate's dose-response relationship needs investigation in future pragmatic trials. Coaches reported a median duration of 10-15 min to complete Activate, suggesting the programme was not implemented as intended. Low exercise fidelity in youth athletes, with players not completing all preventative exercises ${ }^{38} 42$ or performing them incorrectly, ${ }^{42-44}$ has been reported in the literature. It is unclear whether the shorter duration noted in this study is related to issues regarding exercise fidelity, but further evaluation is warranted given the potential negative impact on effectiveness.

Prevention programme maintenance is scarcely investigated, ${ }^{25} 2645$ leaving long-term effectiveness unexplored. Coaches agreed that Activate contains adequate variations and progressions to facilitate maintenance, contrasting findings from the $11+$ whereless than $50 \%$ of coaches and players felt the programme could be maintained for multiple seasons. ${ }^{38}$ Uniquely, Activate can be progressed over weeks, months and seasons, with each age-specific programme containing four phases. This possibly influenced coaches' positive perceptions and this approach should be considered when developing future injury prevention programmes.

Reduced training time as a result of completing Activate was a reported barrier from coaches and players. Similar barriers restricted $11+$ adoption in community football. ${ }^{18} 46$ A recent study found completing 11+ strengthening exercises (part 2) postsession increased adherence without negatively influencing effectiveness. ${ }^{47}$ Before this approach can be advocated for Activate, research needs to explore the mechanistic effect of the programme. Certain exercises were included to reduce specific injuries (eg, isometric neck strengthening for concussion). If these exercises induce chronic long-term effects, they could be omitted from the warm-up and completed at a more suitable time. Conversely, if they induce acute physiological effects, they likely need to be completed immediately prior to exposure. Until this is established it would not be appropriate to recommend completing specific parts, or exercises, postsession as a preventative measure.

\section{Limitations}

To mitigate selection bias, the recruitment database was expanded to include 252 additional schools who did not 
participate in the efficacy study. ${ }^{1}$ In total, $30 \%$ of participating schools in this study were involved in the efficacy study. It is unknown if coaches themselves participated in the previous study. At the time, the programme was not called Activate and it is unclear if previous participation would have influenced coaches' awareness or perceptions towards the programme. A large proportion of respondents were from independent schools despite targeting an equal number of state schools in the recruitment process. Beyond school type, no further demographic information is available for non-respondents, reducing the generalisability of the results and increasing the risk of selection bias.

Surveys administered were an amalgamation of those previously used in football ${ }^{12} 181927$ and rugby. ${ }^{129}$ They have not been psychometrically evaluated beyond face and content validity. Postseason surveys were completed within 6 months of the end of the season to reduce recall bias. ${ }^{48}$ A 7-point Likert scale was used to minimise the effect of any central tendency bias. ${ }^{49}$ Surveys provided no option for free-text answers. Using qualitative methods may provide greater insight into end-user perceptions and contextual issues.

\section{CONCLUSIONS}

This study provides novel findings regarding the implementation of the Activate injury prevention exercise programme in English schoolboy rugby. Coaches had significantly greater awareness and adoption of Activate, with players largely unaware of the programme and if they used it. Coaches appear key stakeholders in the decision to implement Activate in a school rugby environment. Focus on behavioural change in coaches should be a priority to maximise Activate uptake.

\section{Twitter Craig Barden @Cigney}

Acknowledgements Thank you to the schools, coaches and students who participated in the study. Thank you to the Department for Health at the University of Bath for funding the open access charge.

Contributors $\mathrm{CB}$ conceived the initial study concept, with CDM and KAS providing input into the study design and methodology. CB collected and analysed the data, drafting the initial manuscript. Critical revisions were made to the manuscript by CDM and KAS. All authors approved the final submitted manuscript.

Funding The authors have not declared a specific grant for this research from any funding agency in the public, commercial or not-for-profit sectors.

Competing interests $\mathrm{CB}$ completed this study as part of his $\mathrm{PhD}$, which is funded by the Rugby Football Union. KAS is the medical research lead for the Rugby Football Union.

\section{Patient consent for publication Not required.}

Ethics approval The study had ethical approval from the Research Ethics Approval Committee for Health at the University of Bath (EP 17/18 167).

Provenance and peer review Not commissioned; externally peer reviewed.

Data availability statement All data relevant to the study are included in the article or uploaded as online supplemental information.

Open access This is an open access article distributed in accordance with the Creative Commons Attribution 4.0 Unported (CC BY 4.0) license, which permits others to copy, redistribute, remix, transform and build upon this work for any purpose, provided the original work is properly cited, a link to the licence is given, and indication of whether changes were made. See: https://creativecommons.org/ licenses/by/4.0/.
ORCID iD

Craig Barden http://orcid.org/0000-0001-5504-2548

\section{REFERENCES}

1 Hislop MD, Stokes KA, Williams S, et al. Reducing musculoskeletal injury and concussion risk in schoolboy rugby players with a pre-activity movement control exercise programme: a cluster randomised controlled trial. Br J Sports Med 2017;51:1140-6.

2 Hislop MD, Stokes KA, Williams S, et al. The efficacy of a movement control exercise programme to reduce injuries in youth rugby: a cluster randomised controlled trial. BMJ Open Sport Exerc Med 2016;2:e000043.

3 Finch C. A new framework for research leading to sports injury prevention. J Sci Med Sport 2006;9:3-9. discussion 10.

4 Hanson D, Allegrante JP, Sleet DA, et al. Research alone is not sufficient to prevent sports injury. Br J Sports Med 2014;48:682-4.

5 Lindblom $\mathrm{H}$, Waldén M, Carlfjord S, et al. Implementation of a neuromuscular training programme in female adolescent football: 3year follow-up study after a randomised controlled trial. $\mathrm{Br} J$ Sports Med 2014;48:1425-30.

6 Norcross MF, Johnson ST, Bovbjerg VE, et al. Factors influencing high school coaches' adoption of injury prevention programs. J Sci Med Sport 2016;19:299-304.

7 Saunders N, Otago L, Romiti M, et al. Coaches' perspectives on implementing an evidence-informed injury prevention programme in junior community netball. Br J Sports Med 2010;44:1128-32.

8 Thorborg K, Krommes KK, Esteve E, et al. Effect of specific exercisebased football injury prevention programmes on the overall injury rate in football: a systematic review and meta-analysis of the FIFA 11 and 11+ programmes. Br J Sports Med 2017;51:562-71.

9 Barengo NC, Meneses-Echávez JF, Ramírez-Vélez R, et al. The impact of the FIFA $11+$ training program on injury prevention in football players: a systematic review. Int J Environ Res Public Health 2014;11:11986-2000.

10 Al Attar WSA, Soomro N, Pappas E, et al. How effective are F-MARC injury prevention programs for soccer players? A systematic review and meta-analysis. Sports Med 2016;46:205-17.

11 Bizzini M, Dvorak J. FIFA 11+: an effective programme to prevent football injuries in various player groups worldwide-a narrative review. Br J Sports Med 2015;49:577-9.

12 O'Brien J, Finch CF. Injury prevention exercise programmes in professional youth soccer: understanding the perceptions of programme deliverers. BMJ Open Sport Exerc Med 2016;2:e000075.

13 Owoeye OBA, Akinbo SRA, Olawale OA, et al. Injury prevention in football: knowledge and behaviour of players and availability of medical care in a Nigerian youth football League. S. Afr. j. sports med. 2013;25:77-80.

14 Wilke J, Niederer D, Vogt L, et al. Is the message getting through? Awareness and use of the 11+ injury prevention programme in amateur level football clubs. PLoS One 2018;13:e0195998.

15 White PE, Ullah S, Donaldson A, et al. Encouraging junior community netball players to learn correct safe landing technique. J Sci Med Sport 2012;15:19-24.

16 Finch CF, Doyle TLA, Dempsey AR, et al. What do community football players think about different exercise-training programmes? implications for the delivery of lower limb injury prevention programmes. Br J Sports Med 2014;48:702-7.

17 Finch CF. Implementation and dissemination research: the time has come! Br J Sports Med 2011;45:763-4.

18 McKay CD, Merrett CK, Emery CA. Predictors of FIFA 11+ implementation intention in female adolescent soccer: an application of the health action process approach (HAPA) model. Int $J$ Environ Res Public Health 2016;13:657.

19 McKay CD, Steffen K, Romiti M, et al. The effect of coach and player injury knowledge, attitudes and beliefs on adherence to the FIFA 11+ programme in female youth soccer. Br J Sports Med 2014;48:1281-6.

20 Misener K, Doherty A. A case study of organizational capacity in nonprofit community sport. Journal of Sport Management 2009;23:457-82.

21 Glasgow RE, Vogt TM, Boles SM. Evaluating the public health impact of health promotion interventions: the RE-AIM framework. Am J Public Health 1999;89:1322-7.

22 Finch CF, Donaldson A. A sports setting matrix for understanding the implementation context for community sport. Br J Sports Med 2010;44:973-8.

23 Sewry N, Verhagen E, Lambert M, et al. Players' and coaches' knowledge and awareness of the BokSmart Safe Six injury prevention programme: an ecological cross-sectional questionnaire study. BMJ Open 2017;7:e018575. 
24 Steffen K, Meeuwisse WH, Romiti M, et al. Evaluation of how different implementation strategies of an injury prevention programme (FIFA 11+) impact team adherence and injury risk in Canadian female youth football players: a cluster-randomised trial. Br J Sports Med 2013;47:480-7.

25 O'Brien J, Finch CF. The implementation of musculoskeletal injury-prevention exercise programmes in team ball sports: a systematic review employing the RE-AIM framework. Sports Med 2014;44:1305-18.

26 Barden C, Bekker S, Brown JC, et al. Evaluating the implementation of injury prevention strategies in rugby Union and League: a systematic review using the RE-AIM framework. Int J Sports Med 2021;42:112-21.

27 O'Brien J, Finch CF. Injury prevention exercise programs for professional soccer: understanding the perceptions of the EndUsers. Clin J Sport Med 2017;27:1-9.

28 Friedman $\mathrm{HH}$, Amoo T. Rating the rating scales. Journal of Marketing Management 1999;9:114-23.

29 Attwood MJ. Injury prevention in men's community rugby union: movement screening and development of an efficacious exercise intervention.2017; University of Bath - Doctor of Philosophy. Available: https://purehost.bath.ac.uk/ws/portalfiles/portal/ 187948034/ATTWOOD Matthew PhD Thesis 146 17.pd

30 Williams S, Trewartha G, Kemp SPT, et al. Time loss injuries compromise team success in elite rugby Union: a 7-year prospective study. Br J Sports Med 2016;50:651-6.

31 Hind K, Konerth N, Entwistle I, et al. Cumulative sport-related injuries and longer term impact in retired male Elite- and Amateur-Level rugby code athletes and non-contact athletes: a retrospective study. Sports Med 2020;50:2051-61.

32 Davies MAM, D Judge A, Delmestri A, et al. Health amongst former rugby union players: a cross-sectional study of morbidity and healthrelated quality of life. Sci Rep 2017;7:11786.

33 Attwood MJ, Roberts SP, Trewartha G, et al. Efficacy of a movement control injury prevention programme in adult men's community rugby Union: a cluster randomised controlled trial. Br J Sports Med 2018;52:368-74.

34 Brown JC, Verhagen E, Knol D, et al. The effectiveness of the nationwide BokSmart rugby injury prevention program on catastrophic injury rates. Scand J Med Sci Sports 2016;26:221-5.

35 White PE, Otago L, Saunders N, et al. Ensuring implementation success: how should coach injury prevention education be improved if we want coaches to deliver safety programmes during training sessions?: Table 1. Br J Sports Med 2014;48:402-3.
36 Newton JD, White PE, Ewing MT, et al. Intention to use sport concussion guidelines among community-level coaches and sports trainers. J Sci Med Sport 2014;17:469-73.

37 Owoeye OBA, McKay CD, RÄisÄnen AM, et al. Psychosocial factors and the effects of a structured injury prevention workshop on coaches' self-efficacy to implement the $11+$ exercise program. Int $J$ Exerc Sci 2020;13:1459-75.

38 Donaldson A, Callaghan A, Bizzini M, et al. Awareness and use of the $11+$ injury prevention program among coaches of adolescent female football teams. Int J Sports Sci Coach 2018;13:929-38.

39 Emery CA, Hagel B, Morrongiello BA. Injury prevention in child and adolescent sport: whose responsibility is it? Clin J Sport Med 2006;16:514-21.

40 Brown JC, Gardner-Lubbe S, Lambert MI, et al. Coach-directed education is associated with injury-prevention behaviour in players: an ecological cross-sectional study. Br J Sports Med 2018;52:989-93.

41 Steib S, Rahlf AL, Pfeifer K, et al. Dose-Response relationship of neuromuscular training for injury prevention in youth athletes: a meta-analysis. Front Physiol 2017;8:1-17.

42 Owoeye OBA, Emery CA, Befus K, et al. How much, how often, how well? Adherence to a neuromuscular training warm-up injury prevention program in youth basketball. $J$ Sports Sci 2020;38:2329-37.

43 Perera NKP, Hagglund M. We have the injury prevention exercise programme. but how well do youth follow it? J Sci Med Sport 2020;23:463-8.

44 Fortington LV, Donaldson A, Lathlean T, et al. When 'just doing it' is not enough: assessing the fidelity of player performance of an injury prevention exercise program. J Sci Med Sport 2015;18:272-7.

45 DiStefano LJ, Frank BS, Root HJ, et al. Dissemination and implementation strategies of lower extremity preventive training programs in youth: a clinical review. Sports Health 2017;9:524-31.

46 Shamlaye J, Tomšovský L, Fulcher ML. Attitudes, beliefs and factors influencing football coaches' adherence to the $11+$ injury prevention programme. BMJ Open Sport Exerc Med 2020;6:e000830.

47 Whalan M, Lovell R, Steele JR, et al. Rescheduling Part 2 of the $11+$ reduces injury burden and increases compliance in semiprofessional football. Scand J Med Sci Sports 2019;29:1941-51.

48 Choi BCK, Pak AWP. A catalog of biases in questionnaires. Prev Chronic Dis 2005;2:A13.

49 Diefenbach MA, Weinstein ND, O'Reilly J. Scales for assessing perceptions of health hazard susceptibility. Health Educ Res 1993;8:181-92. 